\title{
The role of rotary clubs in post-conflict peace building: a case of northern Uganda (2006-2010)
}

\author{
Joseph Besigye Bazirake*, Paul Bukuluki** \\ College of Humanities and Social Sciences, Makerere University, Kampala, Uganda \\ Tel: +256-772-462100 \\ ${ }^{*, * \star E-m a i l ~ a d d r e s s: ~ b e s i j o e @ g m a i l . c o m ~, ~ p b u k u l u k i @ g m a i l . c o m ~}$
}

\begin{abstract}
This paper presents the Peace building experience of Rotary Clubs in Northern Uganda between 2006 and 2010, so as to identify their contributions in post-conflict peace building processes. Through the Reflective Peace Practice (RPP) analytical framework, the paper presents an insight into Rotary clubs' post-conflict Peace building interventions in the Northern Ugandan districts of Gulu, Kitgum, Lira and Pader. The paper is premised on the theoretical framework of Rotary's outline of international service that identifies the paths to peace as: patriotism, conciliation, freedom, progress, justice, sacrifice, and loyalty. The paper discusses Rotary clubs' peace building projects in Northern Uganda as clustered along three generic lines: the improvement of health, alleviation of poverty, and education support. The effectiveness of the "paths to peace" principles was hampered by challenges such as: the eroded core values of the people owing to life in Internally Displaced People's (IDP) camps, the beneficiary non-ownership of Rotary projects, the difficulty in recruitment and maintenance of Rotary clubs' membership as well as limited funding. The paper acknowledges that Rotary clubs' approaches to peace building especially the peaceplus 'model' has potential if adapted to the local context, to contribute to conflict transformation efforts in post conflict Northern Uganda.
\end{abstract}

Keywords: Rotary clubs; Peace Building; LRA; Northern Uganda; Theories of change; 7-paths; postconflict

\section{INTRODUCTION}

According to its self-description, Rotary International is an association of business and professional leaders united worldwide to provide humanitarian service, encourage high ethical standards in all vocations, and help build goodwill and peace in the world. Rotary International is acknowledged as the World's oldest service association, with the first Rotary club having been created on $23^{\text {rd }}$ February 1905 in Chicago, Illinois, U.S.A by Paul Harris, Silvester Schiele and Gus Loehr (The Rotary Timeline, 2010). This paper specifically examines the role played by Rotary clubs in building 'goodwill' and 'Peace' in post-conflict Northern Uganda between 2006 and 2010.

The conflict in Northern Uganda had its origin in the colonial period, during which British colonial administration created a framework for regional division of labor by ringfencing Southern Uganda for industrial and cash crop production, while the North became a reservoir of cheap manual labor and a pool for recruits into the army, police and Prison 
services (Rodriguez, 2009). The economic and political marginalization of the North, coupled with aspects of ethnic fragmentation, was a deep-rooted aspect of the conflict in the region. (Omara-Otunnu, 1994).

By 1986, a rebellion had been organized by the Holy Spirit Movement (HSM) under Alice Auma, who was described by Behrend (1998) as a local prophet and spirit medium. Alice, popularly known as Lakwena, in reference to the Italian spirit that purportedly possessed her body, lost the battle in Jinja in 1987 where she fled, leaving behind remnants of her HSM forces to regroup under her father, Severino Lokoya. It was during this period that Joseph Kony, a former Uganda People's Democratic Army (UPDA) fighter started conscripting his forces and later combined with Severino Lokoya to form the Uganda Christian Democratic Army. This force eventually metamorphosed into the Lord's Resistance Army (LRA) whose claim to fight for the Democracy and Human rights of the oppressed people of Northern Uganda was undermined by their extreme cruelty, abductions, physical and psychological abuse inflicted upon the populace (Rodriguez, 2009).

\title{
1. 1. Conceptualizing Peace building in relation to Rotary clubs efforts in Post conflict Northern Uganda (2006-2010)
}

\begin{abstract}
"The way to war is a well-paved highway, and the way to peace is still a wilderness." - Paul Harris, co-founder of Rotary International
\end{abstract}

Before 2006, the Government of Uganda implemented several plans for recovery in Northern Uganda. The Northern Uganda Reconstruction Program (NURP- I \&II) between 1992 and 1999 significantly instituted the World Bank-funded Northern Uganda Social Action Fund (NUSAF) to provide grants directly to community groups. However, incidences of corruption dogged the implementation of NUSAF projects; leading to the World Bank's halting of a planned 10- year renewal of NUSAF loans, (Beyond Juba, 2008).

In May 2006, the Ugandan government launched the Emergency Humanitarian Action Plan (EHAP) in response to pressure by the United Nations to address the situation in Northern Uganda more quickly, while the Peace Recovery and Development Plan (PRDP) drafting was ongoing. The projects' scope considered under EHAP included: cessation of hostilities, peace-building and reconciliation, enhanced protection of the civilian population, improved conditions in displacement camps and continued planning for the PRDP. EHAP too, was not short of management challenges, with the reported procurement of low-quality farm implements and seeds as well as the failure to distribute the promised return kits to resettling communities, (Beyond Juba, 2008).

EHAP officially closed with the launch of the PRDP for Northern Uganda in 2007 with four key strategic objectives, viz.: 1. The consolidation of state authority, for which the ultimate outcome was to ensure cessation of armed hostilities, provide security, re-establish the rule of law, enable the judicial and legal services to become functional as well as protect human rights and strengthen local governance through rebuilding state institutions in the region; 2 . Rebuilding and empowering communities to contribute to community recovery and promote an improvement in the conditions and quality of life of displaced persons in camps, completing the return and reintegration of displaced populations, initiating rehabilitation and development activities among other resident communities and ensuring that the vulnerable people would be protected and served; 3. The revitalization of the economy through the reactivation of the productive sectors within the Northern region; and 4. Launch efforts 
towards Peace building and reconciliation in Northern Uganda (PRDP, 2007). However, progress of the PRDP was challenged by the lack of basic services in resettlement areas that threatened the ability of returnees to fully rebuild their communities. Pitner (2011) notes that the LRA's failure to sign a final peace agreement in 2008 coupled with reports about their recruitment incursions in Eastern Congo and in the Central African Republic remained deeprooted threats to peace building in Northern Uganda.

The aim of Peace building is to foster the social, economic, and political institutions and attitudes that will prevent conflicts from turning violent (Doyle \& Sambanis, 2000). Accordingly, post-conflict Peace building seeks to prevent conflicts from recurring where they have already taken place (Rotberg 1996:32). Cousins \& Kumar (2001) propose the creation of stable political processes as a key priority area for Peace building, since other areas of post-war recovery such as the cultural or spiritual spheres remain internal processes where outsiders can only have limited impact and credibility. Boutros Boutros-Ghali (1992) also highlights Peace building as a mechanism to avoid the breakdown of peaceful conditions through cooperative work to deal with underlying economic, social, cultural and humanitarian problems. Tschirgi (2004) concurs that there is a general consensus that Peace building has political, social, economic, security and legal dimensions, each of which requires attention. Accordingly, peace building as a concept came into usage in reference to postconflict action that seeks to identify and support structures which tend to strengthen and solidify peace to avoid a relapse into conflict. (UN, 2004).

Lederach (1997: 38-61), points out that there are three levels which define the actors that facilitate peace building processes in affected populations after internal conflicts. In this regard, three different kinds of actors are categorized in accordance to their sphere of appropriateness as: 1. Top leadership; 2. Middle range leadership; and 3. Grassroots leadership. Whilst Lederach identifies top leadership to include military, political and religious leaders who are highly visible, he notes that these would be more appropriate in dealing with high level negotiations and emphasize cease fire through targeting only a few key people. On the other hand, he identifies middle range and grass root leadership levels as more appropriate in dealing with more people and can be effectively utilized to handle confidence building and reconstruction initiatives. This is partly because many more actors can be strategically engaged at both the middle range and grassroots levels in peace building processes. This paper examines the argument that non-state actors like Rotary clubs can be efficient and suitable to work for peace, especially when dealing with the vast majorities of people at the grassroots and middle range levels. This is partly because non-state actors are less visible, less expensive and more flexible (Rothman \& Ross, 1999), less constrained by narrow mandates, can deal directly with the grass-roots population and have the ability to engage several parties without losing their credibility (Van Tongeren, 1998).

Historical evidence of Rotary clubs' peace building efforts can be traced as far back as the 1940 Rotary convention in Havana, Cuba, where delegates adopted the 'Respect for Human Rights Resolution' which became a precursor to the UN's 1948 Universal Declaration of Human Rights (UDHR). Rotarians at this convention adopted a resolution that became the framework for the UDHR calling for freedom, justice, truth, sanctity of the pledged word, and respect for human rights (Aboo, 2006). In 1942, British Rotarians also convened a conference to plan a world at peace which led to the establishment of United Nations Educational, Scientific, and Cultural Organization (UNESCO) by 1946. The well-founded relationship between Rotary and the United Nations is also credited for contributing to the formation of the United Nations organization. In effect, Zober \& Farber (2003) confirm that 49 Rotarians served in 29 delegations to the United Nations Charter Conference in 1945 held 
in San Francisco. These delegates helped to shape the text and to focus the charter, particularly on economic, social and humanitarian issues. Rotary's record of commitment to Peace building is further exemplified by previous annual themes reflecting a devotion to Peace such as: 1981-1982 - World Understand and Peace; 1987-1988 - Rotarians United in Service Dedicated to Peace; and in 1995-1996- Act with Integrity, Serve with Love, Work for Peace (RGBF, 2000). The 2012-2013 Rotary year theme that coincided with the drafting of this paper had also been dedicated to 'Peace through Service'.

The Rotarian magazine (1997, March) reports that at the 1997 Rotary Peace Forum in Ushuaia, Tierra del Fuego in Argentina, delegates encouraged the continued status of Antarctica as a continent for all people, stressing the importance of peaceful, non-political international collaboration. Rotary's commitment to Peace building was further expounded in the International's Presidential Conference of Peace and Development in 2002 held in Kuala Lumpur, Malaysia where assurances were made to promote the endeavor of Rotarians at all levels in the arena of conflict prevention through pledges to: 1) Work together on conflict resolution using the existing programs of Rotary International and the Rotary Foundation, especially Rotary Centers for International Studies; 2) Enhance people-to-people diplomacy in the promotion of goodwill, world understanding, and peace; 3) Increase the funds available for peace research; 4) Develop training and educational programs for conflict prevention and resolution; and 5) Use Rotary resources and goodwill for the development and the alleviation of injustice, poverty, hunger, sickness, and illiteracy.

This paper notes that Rotary International's principle strategy for peace building is achieved mainly through its education programs around the world that promote cross cultural linkages and encourage the demystification of prejudices among people of diverse backgrounds. This strategy was brought further to the fore through the 2002 Honolulu declaration when a recommendation to adopt a Peaceplus program was proposed. The Peaceplus program was to be modeled along the global success scored by the Polioplus campaign in the fight against polio since 1985. The Polioplus campaign successfully enforced a global vaccination program spearheaded by Rotary international in partnership with UNICEF and the Bill \& Melinda Gates foundation. The proposed Peaceplus program was therefore premised on the assumption that like Polio, violence required an antidote. Peace education for youth and children was therefore proposed as the appropriate antidote against violence, according to this formula:

Violence (disease) + Peace education (antidote) $=$ Violence free society

According to Stewart (2003), the Peaceplus program would entails the integration of peace education in all schools around the world in order to complement the UN culture of peace program and give impetus to the Hague appeal for peace education.

\section{METHODOLOGY}

\section{1. Design}

This paper is based on a study that employed a case study and descriptive research design and heavily relied on qualitative data. This design proved to be an effective approach in the exploration of the role of Rotary clubs in post-conflict Northern Uganda. Comparable to the propositions of Bouma \& Atkinson (1999), a set of variables in Rotary's seven paths to peace were qualitatively considered to establish the relationship between Rotary clubs' activities and Peace building in the area of study. 
The study was carried out in the four Northern Ugandan districts that hosted Rotary clubs i.e. Gulu, Lira, Pader and Kitgum. Lira District is predominantly occupied by people of the Lango tribe who were confronted with a situation of dilapidation where socio-economic, cultural and political structures had been completely demolished in the aftermath of the LRA war (FHRI, 2009). On the other hand, the people of the Acholi tribe who principally inhabit the districts of Gulu, Pader and Kitgum faced intense levels of abductions, displacement, killings and maiming during the LRA war (Rodrigues, 2009). The four selected districts were located in the North central region of Uganda and stood out as some of the most affected areas by the LRA insurgency, according to the PRDP (2007).

\section{2. Sampling procedure}

In this study, a purposive non-probability sampling procedure was undertaken in which primary respondents were contacted from within the Rotary clubs of Gulu, Kalongo Hospital(Pader), Kitgum and Lira. The selected individuals were those who had been in leadership positions in their clubs between 2006 and 2010. In addition to this, snowball sampling was employed to reach out to beneficiaries and partners in Rotary-supported peace building activities in Northern Uganda. The targeted population encompassed individuals involved in the various processes, centered on Rotary clubs' projects such as: 1) Members of Rotary clubs; 2) Officials from Rotary District 9200 and Rotary International; 3) Community members and beneficiaries of the Rotary clubs' projects; 4) Former Rotary peace scholars; and 5) Officials from institutions/organizations that had received grants from the Rotary foundation in the study area between 2006 and 2010. This study population ensured a credible representation of Rotary affiliated peace building activities and contributed to an objective assessment on the role of Rotary clubs in post-conflict Peace building in Northern Uganda.

\section{3. Data collection}

Data was mainly collected using four tools: Interviews (face-to-face and telephone), Focus Group Discussions (FGD), Document review, and online discussion forums. Face-toface and telephone interviews were conducted with key informants, while focus group discussions were held with one community group and three Rotary/Rotaract club members. Rotary information from electronic sources such as the Rotary District 9200 websites, the Rotarian monthly magazines, club memos and presentations by past club leaders, club Newsletters as well as records from clubs' respective secretariats were helpful in providing supplementary documentary data for the study. In addition, discussions in forums such as Rotarians on the Internet (ROTI) and the Rotary Peace Building Community (RPBC) contributed to information relating to Rotary and Peace building on top of recommending some key respondents in the buildup of the snowball sample.

\section{4. Data analysis and processing}

The qualitative data collected was scrutinized descriptively classified using the themes derived from the study objectives. Data was then interpreted, drawing meaning from it and comparing it with other scholars and later presented meaningfully in this paper. 


\section{5. Ethical considerations}

Informed consent was obtained from all study participants prior to conducting the interviews. Study participants were informed about the purpose of the study and the issues that were to be covered. Confidentiality was ensured through making sure that only aggregate information without subject identifiers was used in analysis and writing reports and articles. All data was stored in a safe location accessible only to the study team. Ethical review clearance was obtained from Makerere University School of Arts Research and Higher Degrees Committee prior to commencement of the study.

\section{STUDY FINDINGS AND DISCUSSION}

Generally in Rotary circles, peace is built in varied ways. The mission of the Rotary Foundation is to enable Rotarians to advance world understanding, goodwill and peace through the improvement of health, the support of education, and the alleviation of poverty. This paper highlights the findings on the role played by Rotary clubs in peace building in Northern Uganda as per the Rotary's Mission.

\section{1. The contextual basis for Peace building in Northern Uganda.}

Respondents described the context in Northern Uganda between 2006 and 2010 as one plagued by uncertainty on the status of the LRA rebellion. In a focus group discussion in Okwaloagabo village in Lira, a participant noted,

"We do not know if the war is really over, since we hear that Kony and his men are still fighting somewhere else..." "

Despite the peace talks between the Ugandan government and the LRA that began in Juba in 2006, the sudden standoff in 2008 contributed to the uncertainty within the communities. Nonetheless it was noted that whereas there was general interest expressed by the people to return to their original homes, there was still fear that the rebels who had reportedly moved further to the Democratic Republic of Congo (DRC) and Central African Republic (CAR), could possibly return. One Rotarian in a key informant interview in Lira town, provided an insightful description of the people's desperation:

"...There is now a mushrooming begging culture, people expect someone else to do everything for them, and yet this was not the case before the war. People from here [Lira] were known to be strong and resilient.., but the war destroyed all that... the war destroyed the social fabric that defined people in this region ${ }^{2,}$

One of the key challenges faced by communities returning to their original homes was that they had been away from their ancestral lands for a lengthy period of time. Moreover, it was reported that the people who would have been able to trace ancestral lands had also died

\footnotetext{
${ }^{1}$ The FGD in Okwaloagabo village on 15-03-2011 had 7 participants in attendance (1 woman and six men).

${ }^{2}$ Interview with Rotarian Dr. David on 15-03-2011 in Lira town.
} 
in the IDP camps. Access to land was therefore viewed as a potential source of conflict in the aftermath of the war, posing a challenge to post conflict resettlement in Northern Uganda.

"...Some people had been born in camps and had now become of age and for those who lost their parents, they had no idea of how to trace their homes. Others had been married in the camps and lost their spouses, but had no idea where their spouses came from; so it was difficult for them to find a place to return to. ${ }^{3, "}$

In addition, the undeveloped infrastructure in the villages, owing to the disruptions of the war hindered access to water, health services and roads, making it difficult for people to return as some respondents explained:

"Some people wanted to return home, but the question was, return to what? There was need to put up some facilities in order to enable people to return to their homes ${ }^{4}$ "

\section{2. Theories of change behind Rotarians interventions in post-conflict Northern Uganda}

The mission of the Rotary Foundation is to enable Rotarians to advance world understanding, goodwill and peace through the improvement of health, the support of education, and the alleviation of poverty. Rotary's country [Uganda] peace officer in a key informant interview in Lira reasoned that:

“. . whereas peace is not tangible, it is at the other end of a number of activities and can only manifest itself in certain forms..."

In the Rotarians' pursuit to contribute to peace therefore, it was recognized that peacework involved putting the 'right' conditions in place. In this regard, the micro Theory of Change (ToC) that came up in the study was that:

TOC 1: If we provide social services and encourage economic empowerment, then this will reduce conflict at the domestic level resulting in building peace in the community. ${ }^{6}$

Such efforts were backed by the protection of 34 spring wells and construction of 17 boreholes between 2007 and 2009 in the war-ravaged areas of Ogur, Apala, adekokwonk, and Amac sub counties of Lira District. In addition, repair work had been completed for 16 boreholes and 16 rain-harvesting tanks had been installed by Rotary clubs in Lira, Gulu, Kitgum and Pader. One female respondent exemplified the relief of having access to water:

\footnotetext{
${ }^{3}$ Interview with David of GLCCR, on 14-07-2011 at pece, Gulu town.

${ }^{4}$ Interview with David of Great Lakes Centre for Conflict Resolution (GLCCR) on 14-07-2011 at pece, Gulu town.

${ }^{5}$ Interview with Rotarian Levy in Lira on 15-03-2011

${ }^{6}$ Interview with Rotarian Dr. Olwit in Lira on 15-03-2011
} 
"We used to walk a long distance for water, but now we can
have it anytime with this borehole constructed by Rotary ${ }^{7 .}$

Household economic empowerment was also supported, with evidence in the 'Adopt a village' project in Okwaloagabo, where 8 plough-bulls, 8 exotic breeding Billy goats and an unverified quantity of improved seeds were systematically availed to the community members and individual households. In addition, there existed a Rotary community Corp (RCC) in Adyaka village in Lira, which supported bee keeping and poultry rearing activities. The RCC also supported orphans and vulnerable children (OVCs) in schools. The RCC had distributed equipment such as hoes and pangas to widows, old people and people with disabilities, in a bid to support their wellbeing.

The Rotary club in Lira also supported resettlement by being a conduit for the provision of 280 families with resettlement packages worth $\$ 500$ each. This had impact in terms of building the sense of security and providing for a rejuvenation of the livelihoods of the former IDPs. In Gulu, the Rotary club installed a grinding mill in Koch kalong village, which contributed to a reduction in the distances that people would walk to grind their maize and millet. It was argued by Rotarians that when social services like these were brought nearer to the community members, then this would reduce on domestic violence, owing to the reduced delays in performing household duties particularly on the part of women.

However, the line of providing basic services is a less effective strategy since it requires expensive logistical systems according to CARE (2011). In this regard, more effectiveness in such a strategy would be scored if the underlying causes of poverty could be addressed, through empowering people to change the policies that keep them poor, rather than substituting the state's responsibility to provide such services. It could be stated however, that in the post-conflict situation of Northern Uganda, confidence building was an equally necessary intervention for future development work to be hinged firmly. Rotarians can be said to have contributed to confidence building in Northern Uganda with their efforts between 2006 and 2010.

Rotarians acknowledged that whereas it was the role of the Government of Uganda to provide services for the people, they only made a contribution in the places where such services would be lacking. By this contribution, Rotarians saw themselves as addressing the societal bottlenecks that would have otherwise brought about conflict in the long run. The macro ToC was thus derived as:

ToC 2: If we provide the services that the people are demanding for, then we would contribute to a reduction in the community tensions and reduce on an apparent feeling of abandonment by the people and thereby, decrease on the possibilities of people rising up in arms against the sitting government. $^{8}$

Evidence for this ToC was provided by the way Rotarians intervened to improve on health services. Rotarians in Gulu mobilized for the acquisition of an ambulance at Kalongo hospital which was used to effectively address medical emergencies in the region, such as the yellow fever outbreak of 2010. Also in Okwaloagabo village, Rotarians in Lira worked with partners to construct a health centre to serve the over 3,000 residents of the village. In

\footnotetext{
${ }^{7}$ A female participation in an FGD in Okwaloagabo village on 15-03-2011. (Translation by Rotarctor Max)

${ }^{8}$ Interview with Rotarian Gerald in Gulu on 18-03-2011
} 
addition, Rotarians in Lira responded to the overwhelming cases of disabilities that had been inflicted by the maiming tactics of the LRA rebels by providing up to 155 people with prosthetic limbs through the International Rotary Jaipur limb project in 2006. The Rotary Club of Kitgum on the other hand installed 19 maternity beds in eighteen health centers within the club's first year of existence in 2009. The club also supplemented the beds by the provision of 600 mama kits to the selected health centers. To further promote health amenities in the region, the Rotary club of Kitgum constructed washrooms in two community schools. The club also constructed a Pit latrine in St. Bakhica primary school, which had been earmarked for closure by the ministry of Education over poor sanitary conditions. The Rotary club of Gulu also provided logistical support and training to resettling communities in eight model villages, in addition to the sixteen blocks of Latrines that were constructed in Primary schools.

It is worth noting that the involvement of Rotary clubs in health-related projects that aimed at Peace building in Northern Uganda is similar to the thesis fronted by the Health and Conflict project at the University of New South Wales (2004) which operates under the presumption that as a result of conflict, the wider secondary health effects have long term impacts on the capacity of societies to rebuild. Accordingly, health improvement was considered as an avenue for providing an additional and critical track for long-term development and peace-building in Northern Uganda.

Evidence for Rotary's macro ToC in post conflict Northern Uganda was also provided by the way the clubs in the region supported processes that were directly linked to the education of children, youth, former war combatants and peace workers. In fact, the approach to education in peace building was found to be applied in a way that prepared individuals not only to receive the essential transformative experience that access to education provided, but also to also for the individuals to be prepared to become channels for transforming the rest of the communities.

By 2010, two individuals in Northern Uganda had completed a Rotary peace fellowship; a Master's level degree course conducted for individuals dedicated to a lifetime career in peace work. Notable among the contributions of the Rotary peace fellows in Northern Uganda was the establishment of the Great Lakes Center for Conflict Resolution (GLCCR) as an independent not-for profit and non-governmental organization working for conflict prevention and peace building in Uganda. GLCCR reportedly supported 28 local NGOs and 6 District administrative teams through training, follow up and workshops for experience sharing in the area of peace building. One of the Rotary peace fellows was also found to be operating St. Peters junior school in Gulu to support childhood education at the community level.

Provision of local scholarships and education support by Rotarians was also commonplace, with the Rotary club of Lira facilitating up to 30 teenagers to finalize secondary school or technical/vocational training between 2008 and 2010. The Rotary club of Gulu also received and distributed 100 tons of textbooks from the Rotary Club of Beaverton (US) and these were distributed to various schools and institutions in the districts of Gulu, Kitgum, Pader, Amuru, Lira, Oyam, Apac. Some of the books were used to support the creation of a children's library in Gulu. The Club also donated desks and playing facilities to Our Lady of Good Counsel Nursery and Primary School in Kabedopong in Gulu Municipality. Local organization such as Latin Balle $P e^{9}$ were supported through a Rotary grant to facilitate 124 formerly abducted girls and orphans with scholarships for formal

\footnotetext{
9 'Latin Balle Pe' translates as 'The child is innocent'
} 
education. It is note-worthy that the efforts to support education as advanced by Rotarians in post-conflict Northern Uganda sought to contribute to the reform of mechanisms that address grievances, which would otherwise have fueled future conflicts. However, it was notable from this study that the scale and impact of Rotary projects in terms of education coverage was limited in comparison to the level of need in Northern Uganda. According to Dieltjens and Meny-Gilbert (2008), access to education is a complex problem, which cannot be addressed by providing facilities alone, but must include deliberately designed poverty alleviation strategies. This paper notes that Rotarians' efforts were a purposeful step in the right direction.

\section{3. Rotary's 7-Path approach to peace building}

Reflections undertaken in this study indicated that Rotary club projects in Northern Uganda essentially aimed at spreading impact to individual beneficiaries. There was a notable preference for project impact at the individual and household levels, rather than attempt to affect policies at the wider social-political level. It was noteworthy therefore that the projects carried out by Rotary clubs in Northern Uganda essentially involved the provision of services and equipment aimed at promoting community relationships by seeking to improve on the livelihood for the beneficiaries. The reflections on Rotary's approach to Peace building were augmented by the provisions of Rotary's outline of international service, which identifies a 7path strategy in peace building whose application in Northern Uganda was extracted as follows:

\section{3. 1. The Path of Patriotism}

\section{Rotarians will look beyond National patriotism and consider themselves as sharing responsibility for the advancement of international understanding, goodwill, and peace. Rotarians will resist any tendency to act in terms of national or racial superiority. (Rotary International, 1959, 7)}

The nature of international partnerships involved in the projects reviewed within this study was in line with Rotary International's description of the Path of patriotism, which challenges Rotarians to share responsibility for the advancement of international understanding, goodwill, and peace by looking beyond National patriotism. Findings indicate that members of Rotary clubs in USA (Rotary club of St. Thomas in Virgin Islands, Rotary club of Colville and Rotary club of Redland Sunrise) and Rotarians in Denmark (Rotary club of Bainbridge islands and the Rotary club of Frederiksberg) worked closely with Rotary clubs in Northern Uganda to contribute to peace building efforts in the region.

Rotarians in Northern Uganda expressed their sensitivity about acting in ways that would be deemed either regionally or tribally inclined. Rotarians in Lira reported that their decision to harmonize the distribution of benefits like prosthetic limbs across the Northern region was initially considered scornful by those who considered their tribes to have been victimized by perpetrators from another tribe. This sentiment was expressed by the Langi People of Lira, given that the LRA leader, Joseph Kony, belonged to the Acholi tribe.

Tolstoy (2008) points out that in order to have peace; one must deal with what produces war. Accordingly, Tolstoy points out that patriotism which manifests in the desire for an exclusive good for one's own nation is often one of the underlying causes of war. Tolstoy 
therefore acknowledges that to have peace, it is necessary to abolish patriotism. This paper argues that tribal sentiments can be a misleading form of patriotism, with the possibility of undermining peace efforts. The path of Patriotism as undertaken by Rotarians therefore identifies individuals as world citizens by emphasizing the need to overcome limiting affiliations in order to build concerted efforts towards peace building.

\section{3. 2. The Path of Conciliation}

Rotarians will seek and develop common grounds for agreement with peoples of other lands. (Rotary International, 1959:12)

Rotarians interviewed for this study reported that in service provision, great care had been undertaken to ensure that the location of the services remained significant in healing wounds and in uniting conflicting groups. A Rotarian in an in depth interview narrated an inter-village rivalry that existed as a result of the war:

"The jiong clan and one of its neighbors had been at war with each other for several years. This had been because during the [LRA] war, one child was abducted from one of the villages and when in captivity, he lied to the rebels that he was from another village. One day, however, he managed to escape, and in reprisal, the rebels attacked the village that the boy had claimed to have originated. The rebels tortured people and killed many, asking the villagers to surrender the escapee. At the mention of his name during the brutal hunt, some of the locals who knew him tried to explain to the rebels that the person they were looking for was not one of their own, but was from the next village! This all fell on deaf ears, and the torture continued... ${ }^{10 "}$

After this incident, hatred between the villages grew immensely because of what one village considered as a betrayal of another village's member. Therefore, in view of that scenario, the Rotary club of Gulu, in a spectacular invocation of the path of conciliation, built a borehole within the boundary that separated the two villages.

The launch of the borehole was reported to have intentionally coincided with the memorial of the torture incident, with a deliberate move to have religious and community leaders in attendance. At the launch, it was reported that one of the community elders remonstrated:

"We cannot continue to be in hatred. We have put a borehole here to help us work together. This is something that happened [in reference to the killings] and we cannot continue to be in hatred... we must learn to forgive. ${ }^{11}$ ",

\footnotetext{
${ }^{10}$ As narrated by Rotarian Gerald in an interview in Gulu on 18-03-2011

${ }^{11}$ Ibid
} 
Documentary evidence confirms that the path of conciliation had been similarly applied by Rotarians to settle the 1933-35 Chaco-wars between Bolivia and Paraguay. According to Zober \& Farber (2003), Chilean Rotarians had worked with Rotarians in the two rival countries to form a commission to work out the basis of a peace agreement. Conciliation as a Path to peace therefore identifies with a point of neutrality that would be a meeting point and a basis for healing between feuding groups.

\section{3. 3. The Path of Freedom}

Rotarians will defend the rule of law and order to preserve the liberty of the individual so that he may enjoy freedom of thought, speech and assembly, freedom from persecution and aggression, and freedom from want and fear. (Rotary International, 1959:17)

In regard to this path, Rotarians sought to achieve freedom from 'want' and 'fear' through offering resettlement packages and means of livelihood for beneficiaries. Rotarians reportedly aimed at decongesting IDP camps through supporting people to receive the sense of freedom from the fear of a lack of livelihood.

Through rehabilitation efforts of victims of war and the provision of education opportunities, Rotarians reportedly sought to contribute to sustainable long term peace through targeting children and youth in a bid to encourage them to move on with their lives, free from the torment of the war experiences.

This paper notes that the psychological torture faced in IDP camps in Northern Uganda and the suffering that people experienced as a result of the war, had been an infringement on their human dignity and freedom. Through offering opportunities to access basic necessities such as water, Education and economic opportunities, Rotary clubs exhibited efforts towards the restoration of the dignity of the people who benefited from Rotary projects in Northern Uganda.

\section{3. 4. The Path of Progress}

Rotarians will support action directed towards improving
standards of living for all peoples, realizing that poverty
anywhere endangers prosperity everywhere. (Rotary
International, 1959: 23)

Livelihood improvement was notably the key strategy within the Rotary peace building docket of poverty alleviation with Rotary clubs in Northern Uganda reporting a target to increase on household income as a way to contribute to community progress.

The Rotary club of Lira conducted the Adopt a village project in Okwaloagabo as a way of providing a blueprint for community progress. Apart from the evidence of the communally owned ox-ploughs and exotic Billy goats, it was observed that there were subsidiary vocations such as brick-laying and irrigable vegetable farming which had mushroomed around water sources. In this paper, it is noted that there was evidence to reflect that progress in one aspect would beget more progress in related aspects, even without the initial intention for such an occurrence. 


\section{3. 5. The Path of Justice}

Rotarians will uphold the principles of justice for mankind, recognizing that these are fundamental and must be worldwide. (Rotary International, 1959. 31)

The ultimate creed for Justice in Rotary was epitomized by the popular 4-way test. It was reported that Rotarians' commit to a personal and institutional critical examination of their actions by subjecting them to a series of questions contained in the 4- way test which states that:

Of things we think, say, or do:

Is it the TRUTH?

Is it FAIR to all concerned?

Will it build GOOD WILL and BETTER FRIENDSHIPS?

Will it be BENEFICIAL to all concerned?

Retrospectively, Rotarians reported that the 4-way test provided the most resounding source of direction for their activities in post-conflict Northern Uganda. The 4-way test was said to have been invoked in the various project build-up processes such as: selecting beneficiaries; selecting areas for project implementation; as well as in designing projects, with the ultimate goal of benefiting all the concerned parties. This was reported to have been the case in projects such as: the provision of prosthetic limbs; the selection of beneficiaries for scholarships; as well as the choice of locations for placement of the water installations in the various Rotary projects in Northern Uganda.

It is notable that transformative peacemaking focuses on the means (process) used to reach the ends, focusing very closely on the process instead of merely the desired outcome. The approach stresses fairness, understanding, respect, and inclusiveness of all parties in order to create a commitment to increasing justice, finding truths and heating relationships." (Peace newsletter, 1996)

By using the 4-way test as a guide for project processes, Rotary clubs exhibited a concern for the judicial process that their projects underwent rather than just their outcome. In addition, the Path of justice according to the manual of Rotary international (1959) goes ahead to challenge Rotarians to uphold the principles of justice and make them world-wide. Accordingly, there was a notable expectation for Rotarians to always be informed and endeavor to inform others about the present status of international law, the prospects for its development, as well as the sacrifices which the establishment of a rule of law might require. There was however no allusion to community engagement along this aspect, even when there was an arrest warrant issued by the International Criminal Court (ICC) for the LRA leader and his top commanders. RPP analyses in the study indicate that Rotarians would have contributed to more understanding and confidence building by offering clarity about the ICC arrest warrants and their possible interpretative logic for the people of Northern Uganda.

\section{3. 6. The Path of Sacrifice}

Rotarians will strive always to promote peace between nations and will be prepared to make personal sacrifices for that ideal. (Rotary International, 1959) 
Whereas this study was premised on an intra-state initiative by Rotary clubs to contribute to peace building in Northern Uganda, Rotarians emphasized that their efforts were aimed at contributing to a peaceful world, arguing that war in one part of the world would affect peace in other parts. Rotarians therefore cherished the value of 'giving' rather than 'receiving' and endeavored to offer services, equipment and time as a way of community support, and without expectation for any form of compensation.

An example of this sacrificial effort was narrated in an in-depth interview with the president of the Rotary club of Lira describing his experiences:

"I was the one taking them [the prosthetic limb recipients] to Kumi... and I would be excited about taking them and bringing others back with their limbs. I would do this without any benefit and sometimes I would even use my own money...Moreover, 1 am just a mere teacher, and I do not even have a motorcycle . . .1 just have a bicycle... ${ }^{12}$,"

It was also reported that Rotarians carried out needs assessments, prepared grant proposals and prepared project plans as a sacrificial undertaking, without the slightest expectation of remuneration.

\section{3. 7. The Path of Loyalty}

Rotarians will urge and practice a spirit of understanding of every other man's beliefs as a step towards international goodwill, recognizing that there are certain basic moral and spiritual standards which, if practiced, will ensure a richer, fuller life." (Rotary International, 1959: 44)

Rotarians reported that their key considerations were underwritten with a desire to create unity in face of diversity. In some of the projects, a notable issue that often arose was reported to have been a concern on how people from different religions and tribes could be brought together.

In regard to this, the Rotary country [Uganda] peace officer in a key informative interview noted that:

"... Peace is not by doing certain things... there are different perspectives to peace... and this can only be defined by the people [in a conflict situation]. This is what determines Rotarians peace work $^{13}$,"

The preceding statement relates to the peace building model, based on community aspirations and emphasizes that loyalty to community-felt needs would be vital for encouraging peace. The path of loyalty in this study was therefore manifested in the community linkages by Rotary clubs, aimed at strengthening community structures. It was therefore reported that Rotarians preferred to work with existing traditional systems to holster service provision.

\footnotetext{
${ }^{12}$ Interview with Rotarian Yapi in Lira on 15-03-2011

${ }^{13}$ Interview with Rotarian Levy in Lira on 15-03-2011
} 
The use of traditional approaches was notable in instances such as: pooling resources and sharing in small groups as witnessed in the Adopt a village project in Okwaloagabo; and the use of elders to identify worthy beneficiaries as was reported for various projects.

\section{DISCUSSION AND CONCLUDING REMARKS}

The RPP analysis in this study indicates that the nature of peace building activities undertaken by Rotary clubs in Northern Uganda between 2006 and 2010 mainly targeted to spread the impact of the projects to a wide beneficiary base. In this research, this was categorized as a more people approach, with a focus on grassroots levels of leadership for peace building in respect to the works of Lederach (1997, 38-61).

In terms of the strategies used by Rotary clubs in Peace building in Northern Uganda, it was noted that the projects carried out impacted mainly the individual level of change for targeted beneficiaries, although some interventions reflected socio-political changes in the communities. An example of the latter changes was reflected in the 'Adopt a village' project in Okwaloagabo and the activities of the Rotary community corps in Adyaka. In addition, Rotary clubs' interventions were notably focusing on providing social services such as education and health as well as the encouragement of economic empowerment in an endeavor to reduce conflict at the domestic level with the expectation that this would result in building peace in the wider community.

Concerning the challenges faced by Rotary clubs in Northern Uganda, it was noted that whereas a more people approach for peace building was reflected in the projects examined in this study, it was reported that the resources available to Rotarians in terms of manpower and the financial capacity of their clubs could only support smaller impact groups. With only four Rotary clubs in Northern Uganda and an average membership of twenty Rotarians per club, there was a logical limitation in terms of the potential of Rotary clubs to harness the full prospects of a more people peace building approach.

It was therefore found that whereas Rotary clubs stood out as non-state actors who were less visible, less expensive and more flexible in accordance with the views of Rothman \& Ross (1999), their size had a direct implication on their level of outreach and thus were not in position to reach vast majorities of people in the area of study. Findings of the study however indicate that a wider impact was recorded where Rotarians worked in partnership with other organizations such as World Vision and Water Aid.

It was also notable that whereas Van Tongeren (1998) presents the view that non state actors are less constrained by narrow mandates, it was found that Rotary clubs maintained a strict apolitical and non-religious stance, which seemed to narrow their mandate in relation to working with key people. It was found that Rotarians preferred to work directly with communities without involving politicians and religious leaders, who, according to this paper, would have been imperative in reconstruction processes in the region.

This was attributed to the Rotary International policy that prohibits any actions that would be interpreted as politically or religiously aligned according to Rotary International (1959). Nonetheless, it was noted that the vision of Rotarians in their interventions that aimed at 'a self-reliant, peaceful, healthy and enlightened community' was firmly adhered to, through an attempt to reach out to beneficiaries 


\section{CONCLUSION}

Rotary International presents a worthwhile framework for peace building in postconflict situations. Through the Rotary clubs' avenue of international service, this study noted that Rotary clubs aspire to make a difference in their communities through the 7-paths to peace framework. It is vitally important to note that the sacrificial efforts of individual Rotarians were an outstanding attribute for their execution of peace building interventions in Northern Uganda. The fact that Rotarians, as a social voluntary group of people, were only engaged in peace building as a way of 'doing good in the world' rather than as an avenue for remuneration for themselves, offers a distinguished edge in peace building efforts. This paper notes that the spirit of voluntarism would be essential in establishing comprehensive peace building efforts that need to target the mitigation of conflict structures with all available resources, and without intrinsic self-interest on the part of peace actors for such destabilizing structures to continue existing.

In addition, it was noted that Rotarians were driven to engage in peace building efforts not as a result of specialized training in peace-related work, but rather by way of using their diverse skills and experience to contribute to reconstruction efforts in communities. This demonstrates that the array of peace building options do not necessarily emanate from theoretically learned skills, but ought to also be based on practical and experiential interventions that can make meaningful contributions to peace. It is no wonder that Rotarians encouraged peace building through support to health, education as well as poverty alleviation. Rotarians in their peace building interventions in Northern Uganda therefore exhibited practicality like the kind that could be sensitively implemented by non state actors.

Considering that Rotarians also pooled resources through monetary contributions to the Rotary foundation was notable as an example of an approach of direct participation and the promotion of linkages among people and institutions to promote peace. The small number of Rotary clubs and Rotarians in this study area backed by their immense efforts in Northern Uganda leaves a lot of room for the Rotary fraternity and other like-minded institutions to contribute to peace building efforts, not only in Northern Uganda, but also in other parts of the world.

\section{References}

\section{Books}

[1] Behrend H., Holy Spirit Movements New World; Discourse and Development in the North of Uganda in H. Hansen and M. Twaddle (eds). Developing Uganda, Kampala: Fountain Publishers, 1998.

[2] Behrend H., Alice Lakwena and the Holy spirits; War in Northern Uganda 1986-97. Kampala: Fountain Publishers, 1999.

[3] Bishop J., \& Hoggett P., Organizing Around Enthusiasms. London: Comedia, 1986.

[4] Bouma G. B., \& Atkinson, G. J. (). A Handbook of Social science Research. New York: Oxford University Press INC, 1999.

[5] Cousins E., \& Kumar C., Peace building as Politics: Cultivating Peace in Fragile Societies. Lynne Rienne: Boulder, CO, 2001. 
[6] Denscombe M., The Good Research Guide. London: Open University Press, 2007.

[7] Droma M., Role of reintegration incentives in peace building: A case of UNRF in Yumbe District. Kampala: Makerere University, 2007.

[8] Lederach J. P., Building Peace: Sustainable reconciliation in divided societies Washington DC. United States Institute of Peace, 1997.

[9] Lederach J. P., Neufeldt R., \& Culberston H., Reflective Peace building. Mindanao: Joan B. Kroc Institute for international peace studies, University of Notre Damme and catholic Relief services Southeast, East Asia Regional Office, 2007.

[10] Orjuela C., Building Peace ir Sri Lanka: a Role for Civil Society? Journal of Peace Research pp. 195-212, 2003.

[11] Peinado M. M., The Role of NGOs and the Civil Society in Peace and Reconciliation. Madrid: Centro de Investigación para la Paz.

[12] Rodrigues S. C., Tall Grass; Stories of Sufferings and Peace in Northern Uganda. Kampala. Fountain Publishers, 2009.

[13] Rotary International, Manual of Procedure; A reference manual for Rotary leaders. Evanston: Rotary International; One Rotary Center, 2007.

[14] Rotberg R. I., Vigilance and Vengeance: NGOs Preventing Ethnic Conflict in Divided. Washington, DC: Brooking Institution press, 1996.

[15] Rothman J., \& Ros M. H., Theory and Practice in Ethnic Conflict Management: Theorizing Success and Failure. London: Macmillan, 1999.

[16] Spiegel J., The Lord's resistance Army in Central Africa. A short timeline. The Enough Project, 2009.

[17] Van Tongeren P., Exploring the Local- The Role of NGOs in prevention and management of conflicts: An international directory. The European platform, for conflict prevention and Transformation, (pp. 21-26) 1998.

\section{Journals}

[18] Anderson R. T., Voluntary Associations in History. American Anthropologist, 73(1) (1971) 209-222.

[19] Cutter A., Peace building: A Literature Review. Development in Practice 15(6) (2005) 778-784.

[20] Doyle, M. W., \& Sambanis N., International Peace building: A Theoretical and Quantitative Analysis. The American. Political Science Review 94(4) (2000) 779-801.

[21] Lazarus, A., \& 'Taylor C., Women and Peace building. Agenda Feminist Media (pp. pp. 91-94). Johannesburg: Agenda: Empowering women for gender equity, 1999.

[22] Maclean S. J., Peace building and the New Regionalism in Southern Africa. Third World Quarterly 20(5) (1999) 943-956.

[23] Ruddy, D., \& Viassenroot K., Kony's Message: A New Koine? The Lord's Resistance Army in Northern Uganda. African Affairs 98(390) (1999) 5-36. 
[24] Tschirgi N., post conflict peacebuilding revisted: Achievements, Limitations, Challenges. New York: International peace academy, 2004.

\section{Reports}

[25] Abbo A., Address by District Governor Abdulhamid Aboo to the Rotary club of Nairobi. World Understanding and Peace day, 2006. Nairobi: Rotary District 9200.

[26] Beyond Juba, Is the PRDP Politics as Usual? Update on the Implementation of Uganda's Peace, Recovery and Development Plan. Kampala: Refugee Law Project and the Human Rights \& Peace Centre, 2008.

[27] CARE, Final Evaluation of CARE Nederland 'Don't Exclude Me' programme; Amsterdam, 2011.

[28] Dieltjens V., \& Meny, G., Poverty, equity and access to education. Wits Education Unit, 2008.

[29] FHRI, Promoting sustainable access to justice for Vulnerable. Baseline survey report. Lira, 2009.

[30] HURIPEC (Human Rights and Peace Centre). The Hidden War: the forgotten people. War in Acholiland and its ramifications or peace and security in Uganda. Kampala and Vancouver: Human Rights and Peace Centre, 2003.

[31] Nyeko P., Children abducted by the Lord's Resistance Army in Sudan. New York: Human Rights watch, Africa, 1996.

[32] OECD., International dialogue on Peace building and state building. Peace building and Statebuilding Priorities and Challenges, 2010.

[33] Olara-Otunnu A., Politics and the Military in Uganda. Makerere, Kampala. United Nations; an Agenda for Development: Report of the Secretary-General, UN Doc A148/935, 1994

[34] United Nations, An Agenda for Development: Report of the Secretary-General. Washington: UN Doc AJ48/935, 1994.

[35] White L. C., Peace by Pieces: The Role of Nongovernmental Organizations. Annals of the American Academy of Political and Social Science, (264, 87-97), 1949.

[36] Zober M., \& Farber, Sow the Seeds of Love, Unite in Service- work for peace. A presentation on the Jerusalem Rotary Club: Unity in diversity, 2003.

\section{Online sources}

[37] Barrett, H. P., War on LRA rebels loses momentum as Kony remains at large. Retrieved August 27th, 2011, from The London evening post:

http://www.thelondoneveningpost.comlafricalwar-on-lra-rebels-loses-momentunii

[38] BBC Uganda, timeline, June 2010. Retrieved July 5th, 2010, from BBC News: http//www.bbc.uk/bbcnews/timeline/Uganda

[39] Department of Political Affairs (DPA). Retrieved June 25t1 2010, from http://www.un.org/Depts/dpalprev-dip/fstprev-dip. 
[40] Ghali B., An Agenda for Peace, Preventive diplomacy, peacemaking and peacekeeping, 1995. Retrieved February 3' 2010, from http://www.un.org/Docs/SG/agpeace.html

[41] Rotary Club of Ely - Hereward. (2009). What Is Rotary. Retrieved July 5th 2010, from http ://www.Rotaryciubely-hereward.crg

[42] Rotary International News, Council approves Fifth Avenue of service, 2010. Retrived February 16th 2011 from:

http://www.Rotary.org/enJmediaandnews/news/pages/1 00428_coil 0_5avenue.aspx

[43] Rotary International News, Rotary helps foster peace and understanding through education, 2010. Retrieved February 10th2011 from:

http:I/www.Rotary.org/enlMediaAndNews/PressCenter/PressReleases/Pages/1 00920_pr_Rot aryhelpsfosterpeace.aspx

[44] Rotary International, Seven paths to peace, 1959. Retrieved June 16th 2010, from http://www.peace. calRotaryssevenpathstopeace.htm

[45] Rotary Manual of procedure, 2010. A reference manual for Rotary leaders. Rotary international, http://www.Rotary.org/Ridocuments/en_pdf/03 5en full.pdf

[46] Stewart Robert, You can make a difference: a personal message, 2005. http//www.peace.caJmessage.htm retrieved on February 15, 2010

[47] The Rotarian. (2003). In search of peace Special report: from the United Nations to Afghanistan, RI'S Lasting Legacy. Retrieved on June $15^{\text {th }} 2011$ from http:1/books.google.comlbooks?id=1zQEAAAAMBAJ\&lpg=PA23\&dq=War\%20betw een $\% 2$ OBolivia $\% 20$ and $\% 20$ Paraguay $\% 20$ Rotary\&pg $=\mathrm{PA} 26 \# \mathrm{v}=$ onepage $\& \mathrm{q}=\mathrm{War} \% 20 \mathrm{~b}$ etween $\% 20 \mathrm{~B}$ olivia $\% 20$ and $\% 20$ Paraguay\%20Rotary\&ffalse

[48] The Rotary Timeline. (2010). Retrieved July 5, 2010, from Rotary global history fellowship: http://www.Rotaryfirst100.org/history/history/un1 story.htm

[49] Tolstoy, Leo. Patriotism or Peace, 2011. Retrieved August 15th from www.nonresistance.org.

[50] UN and Rotary, 2010. Retrieved February 15 from http://www.peace.calUNRotary.htm 